\title{
Teaching Reflection of Vocational Colleges' College Chinese course Based on Constructivism Learning Theory
}

\author{
Ling Zhang \\ School of Education, Yunnan Open University, Kunming, 650500, People's Republic of China \\ zhangling7412@163.com
}

Keywords: vocational college, constructivism learning theory, college Chinese course, teaching reflection

\begin{abstract}
Now college Chinese course demand is getting higher and higher, but actual position is marginal and awkward. The society' rational understanding and degree of attention about college Chinese is very limited. Requirements of vocational college Chinese course teaching are very low level. If vocational college Chinese course practical teaching stay in the form of a single obsolete direct teaching state, it is very difficult to realize the function of the "humanism-aesthetic-tool" trinity. Constructivism learning theory is of great significance to the reform of college Chinese course teaching in vocational colleges. Teachers must improve their teaching philosophy, change teaching strategies and ways and actively develop students' initiative learning. Only through the student's sense of construction, the college Chinese course can play an important role in the Trinity.
\end{abstract}

\section{Vocational colleges' college Chinese course current situation}

(1) College Chinese course is not taken seriously.

Colleges Language Course is an important general course before 1949, it was often served by the master teacher as a course teacher in the famous schools, but in the early 1950s it was fully closed. In the 1970s, well-known educators appeal to that college Chinese course should have a place in colleges' courses. In 1996 the former State Education Commission Higher Education Division proposed conditional colleges and universities to set up college Chinese course to enhance the cultural quality of students. But Higher Education Department of the Ministry of Education issued

《notice on Forwarding (Summary of Seminar on College Chinese Course Teaching Reform in Colleges and Universities)》 until 2007, Peking University, Tsinghua University, Nankai University, East China Normal University and some other universities began to act and put college Chinese course as a compulsory course. Later, some local institutions had also set up a college Chinese course. But more vocational colleges pay attention to form, but not actual effect, opening practical courses such as practical writing course. So far college Chinese course in vocational colleges have not established a compulsory course position. It is known that many vocational colleges have set up it as elective course and even don't open elective course. As the school managers, they even know the importance of the humanities curriculum, but under comprehensive trade-off still willing to abandon the college Chinese course, which has a very realistic reason that students still don't have any effect under learning the college Chinese course.

(2) The teacher is satisfied with the incumbency of indoctrination.

College Chinese course teacher's general reaction is that students learn a few articles well is already very good in vocational colleges and public class is not a professional course when getting a thick classic reading and seeing the limited and available hours, they also think that it is necessary that letting students pass through this course. So choosing a few good poems, doing whatever they can to do some explain about articles, issuing a few questions to be solved for students to discuss. And then giving standard answers that the teacher is very proud of. Teachers in the process of organizing teaching and classroom interpretation cannot lack the four key links: understanding the background--entering the text--reading comprehension-- summering appreciation. [1]Some students can follow the teacher, but a large part of students doze off or play phones, sitting absenteeism. The 
teacher's response is that now students are getting worse, the course is simple but the students do not study well. As for the Trinity curriculum goals, there is no way to know how much knowledge a student gets. As long as the students can pass the test, the students' evaluation will not be bad at the end of period.

(3) Students are not interested in learning.

"Most of teaching content selected into textbooks are good articles that have been proven by history, but after all they are proved by someone else, students have still not accepted."[2] Students on the one hand think that articles in the teaching contents are good articles deserved to study, on the other hand, students also feel that these articles are good articles, teacher's lecturing is also full of passion, but they don't feel tasted when they seriously listen and are afraid that they don't have much language cells. Now, they have to force themselves to study for scores, the teachers are also reasonable and don't have excessive requests. Students think that if they could learn professional courses well, college Chinese course clearance is okay. There is no need to spend more effort on it. The reason of playing the phone in class is that there are more interesting or more important things on the phone to do, now the teachers are very enlightened and don't curb the students' personality, that students don't listen is not all disrespectful to the teacher.

(4) The most urgent problem to be solved of college Chinese course in vocational colleges.

There are many reasons why college Chinese course faces difficulties, such as uncertain national policy, not rigid enough rules, not getting enough attention of school leadership, less time in teaching, students have a limited foundation, not having uniform syllabus, no authoritative textbooks, reality of specialization than generalization heavy, form than effect heavy, teachers and students are lack of confidence, the effect of learning college Chinese course is not dominant, and so on. There are many problems on the surface, but the reasons are very complex. But in the case where the course has been set up and teachers and students have gone into the classroom, which is the most urgent problem need to be solved? It is the problem that enhancing teaching effect. In limited class time and in the "embattled" situation we teachers and students maximize the functions of teaching and learning college Chinese course really feeling the joy and harvest from learning college Chinese course. If students felt the joy and harvest from learning college Chinese course and truly felt the effect of learning college Chinese from a number of aspects, college Chinese course will develop in a benign direction and truly achieve the three-in-one curriculum orientation.

\section{Reflections on teaching problem in vocational colleges based on constructivism learning theory}

(1) Brief introduction to Constructivism learning theory.

"Constructivism learning is the further development after behaviorism theory becoming Constructivism learning theory, which is known as contemporary education psychology is happening in a revolution (Slavin,1994) .”[3]The philosophical thought of Constructivism learning is derived from Kant's synthesis of rationalism and empiricism, its psychological thinking is from the psychologist Piaget's children's cognitive development activities within the theory and integrates Piaget's "self-construction theory" and Vygotsky's "social construction theory", formatting the "meaning of construction" on this basis. In the second half of the twentieth century, the coming wave of information technology takes knowledge production and knowledge innovation as the core and the development of computer network technology are the technical basis of Constructivism learning theory's development and implementation.

1) Constructivism learning theory explains the meaning of study.

"Learning is activity procedure that learners absorb by using feeling and construct meaning, in this process students don't passively accept external knowledge and get the result of effecting with outside world learners' contact. The study consists of two parts: constructive meaning theory and constructive meaning system." ${ }^{[4]}$ The key of construction meaning is playing the initiative of individual. "Sternberg and Katz emphasized the initiative of the individual's key role in the process 
of constructing cognitive structure and seriously explored how to play the initiative of the individual in the process of cognition." ${ }^{[5]}$ Constructivism learning theory emphasizes that learning is not a passive acceptance to external stimulus, learning process is a process that students interacting with the environment occurs schema "assimilation" and "conformance", studying is students themselves growing and development's need and is not passive preparation for seeking a professional in the future, studying process should be happy and make people excited. Studying must be a process of students actively constructing meaning, teachers are faithful partners or senior partners supporting and accompanying student's construction meaning. Constructivism learning theory holds that the purpose of learning is to make meaningful construction and teachers should create conditions to help students construct meaning and help students grow their construct meaning's ability.

2) Constructivism learning theory explains what to study.

What does the student learn? Not textbook. The textbook a just a reference, the study's content is based on the student's original knowledge experience, which is from Vygotsky's "Recent Development Area Theory". The content of study can be decided actively by students and students like and is not determined by teacher unilaterally. This also requires learning content's supporting should be opportune, campaign and have the opportunity to choose. Modern network information technology provides necessary conditions for Constructivism learning.

3) Constructivism learning theory explains how to study.

Constructivism learning theory holds that the key of meaningful study is student initiative's playing. Theorists and practitioners analyzed the characteristics of students' active learning and constantly looked for ways how to play student's initiative. They found such teaching strategies and teaching models.

Paying attention to the establishment of bringing students into the true scene of active learning, problem setting, establishment of real task , learning by organizing activities( the game is a special activity), collaborative learning, creation and utilization beneficial to students' autonomous learning environment, opening class, connection with life and positive effects of student's emotional experience. In short, let knowledge live, let students move up.

The more mature specific teaching modes are "Anchored Instruction”, "Scaffolding Instruction" and "Random Access Instruction".

4) Constructivism learning theory explains results of study.

Evaluation standard of Constructivism learning theory is whether the learning process and outcome are effective constructs. The evaluation of Constructivism learning theory are not limited to standardized examinations and have more emphasis on students' real feelings and feedback in the process of learning, advocating a more flexible way to evaluate learning. "Include real evaluation, portfolio evaluation method, ethnographic research, professional advice, and so on. In addition, in the process of teaching design, have many informal or qualitative e methods such as interview, observation, user note, important group status, experts' reviews and student oral feedback information, and so on. They are more valuable than the data obtained from scale and questionnaire."[6]

(2) Teaching reflection on vocational college Chinese course based on Constructivism learning theory

1) What is college Chinese teaching in vocational college?

Based on Constructivism learning theory, direct teaching of college Chinese teachers in vocational colleges obviously is not useful to students making meaningful construction, teachers use "Old Three Centers", using "teachers, textbooks, classroom" as the center, not putting students as the center. Teachers value their teachings and ignore students' learning, paying attention to how much having given and the wonderful degree of teaching process, not seeing depth and breadth of student's meaning construction of college Chinese, not seeing cultivating ability of student's meaning construction, ignoring student's emotional experience, ignoring edification and influence of attitudes and values. Vocational college Chinese teaching should be a process of teacher supporting and helping students actively construct college Chinese knowledge and promoting 
ability of students actively constructing college Chinese and grooming quality of students actively constructing college Chinese, not is a process of passionately explaining a few classic poetry in limited classroom time. Only students have ability and quality of actively constructing college Chinese, "human - aesthetic - tools" function can be played really in a long term.

2) What vocational college Chinese should teach?

Based on Constructivism learning theory, teachers should analyze students' original knowledge experience, select learning content in the recent development area, make students actively choose learning content as much as possible, analyze content belong to what nature to rationally adopt corresponding teaching strategies.

College Chinese teaching materials are diverse, some emphasis on writing skills, some emphasis on ancient classics, having also integrated model of taking article's subject as a unit. No matter what kind of textbooks, they all have advantages or disadvantages and need teacher to choose and make full use of massive network information resources to provide students chooses. Obviously behavior that satisfying with selecting some limited classic chapters in a textbook is too limited. "What Constructivism learning teaching method need is open and textual textbooks and networked learning environment.”[7]

3) How to Carry out Chinese Teaching in Vocational Colleges?

Learning Chinese courses in middle school is for high scores, everything is in line with the test scores, studying content is standardized exam content and learning has strong utilitarian. Students don't be driven by utilitarian score in the university and limited by standard answer, teachers and students driven by need of fun and intrinsic development can enjoy the fun of learning college Chinese and get harvest of knowledge, ability and literacy. But student's potential can't get developed because of limitations of teaching methods, on the surface is that students are not serious, in fact students can't make a lot of effort. Obviously, direct teaching from secondary school can't satisfy needs of students actively constructing. Vocational college Chinese teaching requires teachers to use effective strategies to let knowledge live and students move up. First of all, teachers should see initiative students have when learning college Chinese, teacher should give student chance to play the initiative and develop ability and quality of student taking initiative to construct college Chinese deeply.

In specific teaching activities, teacher should flexibly use effective strategy of Constructivism learning teaching and interact college Chinese study with college life and build meaningful learning situation and set up problem suiting student to explore and organize variety activities and launch collaborative learning and let students fully experience aesthetic taste and human feelings of learning college Chinese, making full use of massive network resources and borrowing modern information technology In order to play Initiative of student learning college Chinese e.

4) How to evaluate college Chinese teaching in vocational colleges?

Evaluation to student can't be limited to examination paper and textbook content taught directly. It should pay more attention to student learning's process and real experience.

Evaluation to teacher can't be satisfied with student's assessment after easily crossing exam, placing practical problems not seeing or hearing. This evaluation should pay attention to practical application of teacher's teaching strategies.

\section{Discussing the reformation of Chinese teaching in vocational colleges based on constructivism learning theory}

(1) Teacher should improve educational philosophy and constantly reflect.

Teacher should study constantly, even using the way of studying by themselves or vocational training organized by school or higher level. Obviously, learning from all the advanced educational ideas, on the basis of their own original ideas, combining with teaching practice and reflecting in diligent, recognizing teaching problems where exit, exploring the way of solving, which is only way of developing teacher profession and an important way of reforming current college Chinese teaching in vocational colleges. 
(2) Teacher need explore useful teaching methods in practice.

Theory is used to guide practice. All theories need to be proven by practice to justify their reasonable place. Teacher should have awareness of exploring useful teaching methods in practice. Constructivism learning theory is in the ascendant, its specific teaching model and teaching methods need to be studied constantly by people. As for effective teaching method of college Chinese based on Constructivism learning theory whose research is limited.

(3)Attention and support of design layer and management.

Someone said that "If college Chinese course became an independent discipline as Chinese international education course, teaching status of college Chinese could get legal assurance, its unique curriculum features can be fully exploited.”[8] Enhancing effect of college Chinese teaching and practical function of course rely on recognition and support of design layer and management by a certain degree.

In short, vocational college Chinese teaching should move away from shackle of examination education in secondary school, open the door to human spirit, make teachers and students really taste charm of college Chinese and develop initiative of student self - construction and make a fire for the student, which is the really effective college Chinese education in vocational college.

\section{References:}

[1] Wenjie Zhang. Literary classics: The aesthetic world of poetic emotion [J], Journal of higher education research, 2015. 38(1): 100-104

[2] Qingdong Kong. College language's teaching Reformation direction [J], Chinese university education, 2006(7): 20-21

[3] Weidong Yang,Nan Jia. Constructivism learning theory’s evaluation [J], Theoretical journal, 2011

[4] Weidong Yang、Nan Jia. Constructivism learning theory’s evaluation [J], Theoretical journal, 2011

[5] Kekang He. Constructivism learning's teaching mode, teaching theory and teaching design [J], Journal of Beijing normal university( social science edition ), 1997(145): 74-81

[6] Zhixian Zhong. Discussing Constructivism learning's teaching design model [J], foreign education research, 2005. 32(1): 55

[7] Mengcheng Zhao. Evaluation of Constructivism learning's teaching method [J], foreign education research, 2002. 29(9): 15-19

[8] Haijun Guo、 Xudong Zhang. Chinese excellent traditional culture's education and college Chinese course's construction [J], Journal of northeast normal university (philosophy and social science edition.), 2015(2): 181-184 